\title{
PENGARUH PEMBERIAN PENGUATAN TERHADAP MOTIVASI BELAJAR SISWA KELAS V SDN 018 RANTAU SIALANG KECAMATAN KUANTAN MUDIK KABUPATEN KUANSING
}

\author{
Yulia Citra, Syahrilfuddin \\ Yuliacitra247@gmail.com, Syahrilfuddinkarim@yahoo.com \\ Program Studi Pendidikan Guru Sekolah Dasar \\ Universitas Riau, Indonesia
}

\begin{abstract}
ARTICLE INFO
ABSTRACT

Abstract: This research is in the background by the weakness of student learning motivation in the teaching and learning process, one of which is characterized by students tend to be passive and less enthusiastic. The purpose of the study was to find out whether there was an effect of giving reinforcement to students 'learning motivation and how much influence the giving of reinforcement on students' learning motivation. The approach in this study is quantitative with the type of experimental research, the design of this study is pre-experimental. The pre-experimental design used in this study was one pretest-posttest group. The subjects in this study were 27 grade V students of SDN 018 Rantau Sialang with 8 men and 19 women. The variables in this study are the variables of giving reinforcement and student motivation. Data collection using documentation and questionnaires. Validity test using Pearson product moment formula and reliability test using Alpha formula. The analysis prerequisite test used the normality test with the Kolmogrov-Smirnov One Sample test using SPSS 17.0 for windows. Hypothesis testing uses the t test with the help of SPSS and the last effect test. The results showed that there was an effect of giving reinforcement to students' learning motivation, as evidenced by the results of the t test at a significant level of $1 \%$ and $5 \%$ namely tcount $>$ ttable or at level $1 \%(7,751>1,298)$ at the level of 5\% (7,751>1,674). Calculation of the effect test (effect size) obtained by ES is 3.146, this figure is included in the high category because the effect size is more than 0.8. It was concluded that giving reinforcement had an effect on the learning motivation of V grade students of SDN 018 Rantau Sialang Kecamatan Kuantan Mudik Kabupaten Kuansing with a high category.

Submitted:

4 Juli 2019

$4^{\text {th }}$ July 2019
\end{abstract}

Accepted:

17 September 2019

$17^{\text {th }}$ September 2019

Published:

7 Oktober 2019

$7^{\text {th }}$ October 2019
Keywords: giving reinforcement, motivation to learn

Abstrak: Penelitian ini di latar belakangi oleh lemahnya motivasi belajar siswa dalam proses belajar mengajar salah satunya ditandai dengan siswa cenderung pasif dan kurang antusias. Tujuan penelitian untuk mengetahui apakah ada pengaruh pemberian penguatan terhadap motivasi belajar siswa dan seberapa besar pengaruh pemberian penguatan terhadap motivasi belajar siswa. Pendekatan dalam penelitian ini adalah kuantitatif dengan jenis penelitian eksperimen, desain penelitian ini adalah pre-eksperimental. Bentuk preeksperimental design yang digunakan dalam penelitian ini adalah one grup pretest-posttest. Subjek dalam penelitian ini adalah siswa kelas V SDN 018 Rantau Sialang sebanyak 27 siswa dengan 8 orang laki-laki dan 19 orang perempuan. Variabel dalam penelitian ini adalah variabel pemberian penguatan dan motivasi belajar siswa. Pengumpulan data menggunakan dokumentasi dan angket. Uji validitas menggunakan rumus pearson product moment dan uji reliabilitas menggunakan rumus Alpha. Uji prasyarat analisis menggunakan uji normalitas dengan uji One Sample Kolmogrov-Smirnov menggunakan SPSS 17,0 for windows. Pengujian hipotesis menggunakan uji t dengan bantuan SPSS dan terakhir uji pengaruh (effect size). Hasil penelitian menunjukkan bahwa terdapat pengaruh pemberian penguatan terhadap motivasi belajar siswa, terbukti hasil uji t pada taraf signifikan $1 \%$ dan 5\% yaitu thitung $>$ ttabel atau pada taraf $1 \%(7,751>1,298)$ pada taraf $5 \%$ (7,751>1,674). Perhitungan uji pengaruh (effect size) diperoleh ES sebesar 3,146 angka ini termasuk dalam kategori tinggi karena effect size lebih dari 0,8. Disimpulkan bahwa pemberian penguatan berpengaruh terhadap motivasi belajar siswa kelas V SDN 018 Rantau Sialang Kecamatan Kuantan Mudik Kabupaten Kuansing dengan kategori tinggi.

Kata Kunci: pemberian penguatan, motivasi belajar

Citra, Y., \& Syarilfuddin. (2019). Pengaruh Pemberian Penguatan Terhadap Motivasi Belajar Siswa Kelas V SDN 018 Rantau Sialang Kecamatan Kuantan Mudik Kabupaten Kuansing. Primary: Jurnal Pendidikan Guru Sekolah Dasar, 8(2), 115-124. DOI: http://dx.doi.org/10.33578/jpfkip.v8i2.7566. 


\section{PRIMARY : JURNAL PENDIDIKAN GURU SEKOLAH DASAR \\ Volume 8 Nomor 2 Oktober 2019 \\ DOI : http://dx.doi.org/10.33578/jpfkip.v8i1.7566 \\ ISSN : 2303-1514 | E-ISSN : 2598-5949 \\ https://primary.ejournal.unri.ac.id/index.php/JPFKIP}

\section{PENDAHULUAN}

Pendidikan tidak terlepas dari proses belajar mengajar, kita tahu kegiatan belajar mengajar merupakan suatu proses yang mengandung serangkaian perbuatan guru dan siswa atas dasar hubungan timbal balik yang berlangsung dalam situasi edukatif untuk mencapai tujuan tertentu. Salah satu aspek yang berperan penting untuk mencapai tujuan tersebut adalah adanya motivasi belajar. Motivasimerupakan kekuatan (energi) seseorang yang dapat menimbulkan tingkat persistensi dan antusismenya dalam melaksanakan suatu kegiatan, baik yang bersumber dalam diri individu (motivasi intrinsik) maupun dari luar individu (motivasi ekstrinsik) (Kompri, 2015). Tetapi masalah yang sering terjadi adalah motivasi belajar siswa yang rendah pada saat ini menjadi topik yang perlu diperhatikan dalam dunia pendidikan. Lemahnya semangat siswa dalam belajar mengajar ditandai dengan siswa cendrung pasif dan kurang antusias, tidak senang jika diberi tugas oleh guru, enggan untuk dapat mencari dan memecahkan masalah yang berhubungan dengan materi pelajaran dan tetap asyik bermain tanpa memperhatikan guru saat menerangkan pembelajaran. Setiap siswa memiliki karakteristik yang berbeda-beda, motivasi belajar siswa dapat muncul dari dalam dirinya sendiri dan ada juga yang muncul dari luar seperti dari guru saat proses pembelajaran sedang berlangsung. Indikator motivasi belajar siswa dapat dilihat dari pendapat Sardiman (2016) diataranya: 1) tekun menghadapi tugas (dapat bekerja terus-menerus dalam waktu yang lama, tidak pernah berhenti sebelum selesai), 2) ulet menghadapi kesulitan (tidak lekas putus asa), 3) menunjukkan minat terhadap bermacam-macam masalah (misalnya masalah pembangunan, agama, politik, ekonomi, keadilan, pemberantasan korupsi, penentangan terhadap setiap tindak kriminal, amoral dan sebagainya), 4) lebih senang bekerja mandiri, 5) cepat bosan pada tugas-tugas yang rutin (hal-hal yang bersifat mekanis, berulang-ulang begitu saja, sehingga kurang kreatif), 6) dapat mempertahankan pendapatnya (kalau sudah yakin akan sesuatu), 7) tidak mudah melepaskan hal yang diyakini itu dan 8) senang mencari dan memecahkan masalah.

Proses belajar mengajar merupakan hubungan yang terjadi antara guru dan anak diidknya. Guru adalah orang yang memberikan ilmu pengetahuan kepada anak didiknya. Guru juga mengemban banyak peran di lingkungan sekolah. Proses belajar mengajar sebagian besar dipegang oleh guru. Melalui pembelajaran aktif sesuai dengan peran guru dalam kurikulum 2013 bahwasannya guru berperan sebagai motivator, ia bertugas memotivasi siswa ketika proses belajar mengajar sedang berlangsung, dengan memotivasi siswa saat pembelajaran berarti guru berusaha mengajak dan membawa seluruh siswa yang ada di kelasnya untuk aktif, guru tidak boleh hanya fokus pada materi pelajaran saja dan kurang memperhatikan kondisi siswa, misalnya ketika sedang mengoreksi tugas guru juga harus memberi timbal balik kepada siswa dan guru perlu memperhatikan siswa yang masih ketinggalan atau kurang fokus untuk menyelesaikan materi. Guru yang penuh motivasi harus mampu menumbuhkan dan merangsang semua potensi siswa/i nya serta dapat mengarahkan mereka untuk memanfaatkan potensi itu secara tepat. Sebagai guru profesional sudah seharusnya memiliki penguasaan kompetensi pendidikan antara lain menguasai sejumlah keterampilan mengajar. Guru dituntut untuk memiliki keterampilan mengajar yang kompleks. Salah satunya ialah guru harus menguasai keterampilan dalam pemberian penguatan (reinforcement).

Pemberian penguatan (reinforcement) merupakan tindakan atau respon terhadap suatu bentuk perilaku yang dapat mendorong munculnya tingkah laku tersebut, memberi penguatan dalam pembelajaran merupakan suatu tanda persetujuan guru terhadap perilaku siswa (Majid, 2017). Pemberian penguatan secara tepat di dalam kelas dengan berpedoman pada prinsip-prinsip penggunaanya dapat mendorong siswa meningkatkan usahanya dalam kegiatan belajar mengajar. Indikator pemberian penguatan dapat dilihat dari pendapat Majid (2017) dan Daud, dkk (2009) bahwa komponen pemberian penguatan (reinforcement) yang akan digunakan adalah penguatan verbal dan nonverbal. Penguatan verbal menggunakan komentar berupa pujian dan persetujuan yang dapat dinyatakan dalam bentuk kata-kata dengan indikator: bagus, hebat, pintar, 
benar, ya, tepat, betul. Kemudian dalam bentuk kalimat dengan indikator seperti: pekerjaanmu bagus sekali, pekerjaanmu makin lama makin baik, ibu senang dengan pekerjaanmu, caramu memberikan penjelasansangat teratur, ya ini bisa dilanjutkan, ibu setuju dengan kesimpulanmu. Sedangkan ada beberapa penguatan nonverbal berupa mimik/gerak badan dengan indikator seperti: senyuman, anggukan, acungan jempol, kadang-kadang disertai dengan penguatan verbal. Penguatan dengan cara mendekati indikatornya seperti: mendekatnya guru kepada siswa untuk menyatakan perhatian dan kesenangannya terhadap pekerjaan atau perilaku siswa. Penguatan dengan sentuhan indikatornya: guru dapat memberikan persetujuan dan penghargaannya terhadap perilaku penampilan siswa dengan memegang bahu siswa dan mengelus kepala siswa. Penguatan dengan melakukan kegiatan yang menyenangkan indikatornya: guru melakukan kegiatan-kegiatan atau tugas-tugas yang disenangi siswa sebagai penguatan terkait dengan yang diberi penguatan, misalnya: siswa yang berhasil mengerjakan

\section{METODE PENELITIAN}

Penelitian ini telah dilakukan di SDN 018 Rantau Sialang Kecamatan Kuantan Mudik Kabupaten Kuansing. Penelitian dilaksanakan mulai pada bulan Februari sampai Maret tepatnya pada tahun ajaran 2018/2019. Jenis penelitian yang digunakan adalah eksperimen dengan desain preekspremintal. Dikatakan pre-eksperimental design karena desain ini belum merupakan eksperimen sungguh-sungguh karena masih banyak terdapat variabel luar yang ikut berpengaruh terhadap terbentuknya variabel dependen oleh variabel independen (Sugiyono, 2017). Subyek dalam penelitian ini adalah siswa kelas V SDN 018 Rantau Sialang sebanyak 27 orang terdiri dari 8 orang laki-laki dan 19 orang perempuan.

Instrumen yang digunakan dalam penelitian ini berupa kuesioner (angket) dan dokumentasi. Instrumen yang digunakan adalah angket motivasi belajar dengan 8 indikator diambil dari pendapat Sardiman (2016) diantaranya: 1) tekun menghadapi tugas, 2) ulet menghadapi kesulitan, 3) menunjukkan minat terhadap bermacam-macam masalah, 4) lebih senang tugasnya dengan cepat dan benar diperbolehkan untuk istirahat lebih awal dari teman-temannya, bernyanyi bersama di akhir pembelajaran. Kemudian penguatan berupa tanda indikatornya: pemberian simbol seperti tanda cek $(\sqrt{ })$ komentar tertulis pada buku siswa, memberikan stiker berupa senyum dan bintang untuk siswa yang berhasil dalam mengerjakan tugasnya.

Berdasarkan teori yang telah dijelaskan di atas bahwa pemberian penguatan sangat penting dalam proses belajar mengajar, karena pada dasarnya, sifat dasar manusia akan senang dan bangga ketika mendapatkan penguatan berupa pujian dan sebagainya, pemberian penguatan diharapkan memiliki pengaruh untuk dapat meningkatkan motivasi belajar siswa dalam mencapai tujuan yang diinginkan yaitu prestasi belajar yang baik. Tujuan dari penelitian ini adalah untuk mengetahui apakah ada pengaruh pemberian penguatan terhadap motivasi belajar siswa dan seberapa besar pengaruh pemberian penguatan terhadap motivasi belajar siswa.

bekerja mandiri, 5) cepat bosan pada tugas-tugas yang rutin, 6) dapat mempertahankan pendapatnya, 7) tidak mudah melepaskan hal yang diyakini itu, 8) senang mencari dan memecahkan masalah. Sebelum instrumen digunakan terlebih dahulu dilakukan uji kualitas instrumen berupa uji validitas dan uji reliabilitas. Uji validitas instrumen dilakukan dengan tujuan untuk mengetahui kelayakan isi, bahasa dan penyajian dari instrumen yang digunakan.Setelah berkonsultasi dengan pembimbing dan setelah melakukan revisi sebanyak 2 kali terhadap instrumen penelitian, kemudian pembimbing merekomendasikan untuk melakukan konsultasi dengan ahli (expert judgment) dan peneliti juga melakukan uji coba ke SDN 013 Pekanbaru dengan jumlah responden sebanyak 21 orang terdiri dari 10 orang laki-laki dan 11 orang perempuan. Instrumenkemudian diuji cobakan dengan menggunakan rumus pearson product moment. Rumus pearson product momentdigunakan untuk melihat korelasi skor item butir pertanyaan dengan skor total dari butir pertanyaan. 
Jika rhitung telah diperoleh, hasil perhitungan dikonsultasikan dengan harga kritis product moment dengan ketentuan rhitung>rtabel dengan taraf signifikan 5\% maka butir instrumen dikatakan valid. Bila harga korelasi rhitung $<$ rtabel maka dapat disimpulkan bahwa instrumen tersebut tidak valid. Dengan demikian dapat dilihat bahwa nilai untuk rtabel $(0,432)$ sedangkan nilai rhitung bergerak dari rentang nilai 0,506 sampai 0,952 artinya dari 28 item instrumen angket penelitian yang telah diuji maka semua item dinyatakan valid. Karena nilai $r_{\text {hitung }}>r_{\text {tabel }}(0,506>0,432<0,952)$.

Ujireliabilitas instrumen untuk menunjukkan suatu pengertian bahwa suatu instrumen dapat dipercaya untuk digunakan sebagai alat pengumpulan data. Uji reliabilitas dalam penelitian ini menggunakan rumus Alpha. Untuk mempermudah penghitungan peneliti menggunakan bantaun SPSS 17,0 for windows. Pengujian dilakukan dengan membandingkan antara nilai alpha cronbach dengan 0,60. Berdasarkan pengolahan data menggunakanSPSS 17,0 for windows diperoleh nilai alpha variabel $\mathrm{X}$ dan $\mathrm{Y}>\mathrm{r}$, nilai reliabilitas kedua variabel berada di atas angka 0,60 yaitu sebesar 0,982. Sehingga dapat dikatakan semua konsep pengukur masingmasing variabel dari kuesioner adalah reliabel sehingga untuk selanjutnya item-item pada masing-masing konsep variabel tersebut layak digunakan sebagai alat ukur. Sedangkan instrumen berupa dokumentasi dalam penelitian ini diambil selama peneliti melaksanakan penelitian di SDN 018 Rantau Sialang yang berguna sebagai alat bukti penguat bahwa peneliti memberikan penguatan selama berada di dalam kelas yang akan dideskripsikan peneliti pada hasil penelitian pemberian penguatan dan beberapa foto bukti pemberian penguatan disetiap pertemuan. Indikator pemberian penguatan yang digunakan peneliti

\section{HASIL DAN PEMBAHASAN}

Hasil penelitian yang diperoleh terdiri dari skor pretest dan posttest motivasi belajar siswa kelas V SDN 018 Rantau Sialang Kecamatan Kuantan Mudik Kabupaten Kuansing peneliti melakukan analisis data pretest dan posttest dari data angket motivasi belajar siswa yang telah peneliti rekap menjadi tabulasi angket motivasi diambil dari pendapat Majid (2017) dan Daud, dkk (2009) bahwa komponen pemberian penguatan (reinforcement) yang akan digunakan adalah penguatan verbal dan nonverbal. Penguatan verbal menggunakan komentar berupa pujian dan persetujuan, sedangkan ada beberapa penguatan nonverbal diantaranya: 1) penguatan berupa mimik/gerak badan, 2) penguatan dengan cara mendekati, 3) penguatan dengan sentuhan, 4) penguatan dengan melakukan kegiatan menyenangkan, 5) penguatan berupa tanda.

\section{Distribusi Frekuensi}

Ialah daftar nilai yang telah di kelompokkan disertai dengan nilai frekuensi yang sesuai. Pengelompokkan data ini dimaksudkan agar ciri-ciri penting data tersebut dapat segera terlihat. Pengeluaran distribusi frekuensi dari data pretest dan posttest motivasi belajar siswa diantaranya: $\mathrm{N}$ atau jumlah data yang valid, Mean, Median, Mode, Std Deviation, Range, Minimum, Maximum dan Sum.

\section{Uji Prasyarat}

\section{Uji Normalitas}

Uji normalitas dihitung untuk mengetahui apakah data yang terkumpul berdistribusi normal atau tidak. Uji normalitas dalam penelitian ini menggunakan uji kolmogrov-Smirnov dengan bantuan SPSS 17,0 for windows. Data dinyatakan berdistribusi normal jika signifikansi $>0,05$

\section{Uji hipotesis}

Uji perbedaan rata-rata untuk mengetahui apakah terdapat perbedaan rerata pretest secara signifikan dengan rerata posttest

\section{Uji Pengaruh}

Uji pengaruh dilakukan untuk mengetahui seberapa besar pengaruh variabel $\mathrm{X}$ terhadap variabel Y.

belajar siswa. Angket penelitian terdiri dari 28 butir pertanyaan yang telah teruji ke validitan nya melalui (Expert Judgment)serta melakukan uji coba ke SDN 13 Pekanbaru kelas VB dengan jumlah siswa 21 orang yang mana 10 orang lakilaki dan 11 orang perempuan dan telah diuji validitas dan reliabilitasnya. 


\section{Motivasi Belajar}

Pada penelitian ini peneliti melakukan pengumpulan data motivasi belajar menggunakan angket, yaitu angket pretest dan posttest, angket pretest motivasi belajar diberikan sebelum peneliti melakukan treatment dan angket posttest motivasi belajar diberikan setelah peneliti melakukan treatment. Berdasarkan penggunaan data pretest dan posttest maka peneliti dapat melihat apakah ada perbedaan dari hasil pretest dan posttest nantinya, hal ini bertujuan untuk mengetahui ada pengaruh pemberian penguatan dan seberapa besar pengaruhnya terhadap motivasi belajar siswa sebelum dan sesudah dilakukannya treatment.

\section{Pemberian Penguatan}

Pada penelitian ini pemberian penguatan disebut sebagai treatment yang akan dilakukan peneliti saat turun ke lapangan yaitu di kelas $\mathrm{V}$ SDN 018 Rantau Sialang Kecamatan Kuantan Mudik Kabupaten Kuansing, pengumpulan data pemberian penguatan yang digunakan peneliti di sini ialah dilihat dari video yang diambil selama pertemuan berlangsung. Jadi selain menggunakan data pretest dan posttest, peneliti juga menggunakan dokumen berupa foto dan video yang digunakan untuk melihat penerapan dari pemberian penguatan dari peneliti sendiri. Deskripsi pemberian penguatan selama pertemuan akan dijelaskan secara jelas di bawah ini:

\section{Pertemuan Pertama}

Pemberian penguatan berjalan cukup baik, peneliti memberikan penguatan disetiap kegiatan yang dilakukan oleh peserta didik yang dimulai dari kegiatan pendahuluan, peneliti hanya memberikan penguatan verbal berupa katakata/kalimat seperti: ya, bagus, hebat, ya pintar anak ibu disini peneliti melaksanakan penguatan disaat peserta didik sudah bisa menjaga kebersihan kelasnya dan juga pada saat kegiatan apersepsi, kemudian di kegiatan inti peneliti lebih sering memberikan penguatan nonverbal seperti: mendekati siswa, tepuk tangan, anggukan, senyuman, memegang bahu, mengusap kepala, acungan jempol dan penguatan berupa tanda tetapi juga ada beberapa penguatan verbal yang diberikan oleh peneliti kepada peserta didik dalam beberapa kegiatan mulai dari ayo membaca, mengerjakan
LKPD disertai dengan melakukan percobaan. Begitu juga pada kegiatan penutup peneliti hanya beberapa kali memberikan penguatan yaitu pada saat menyebutkan secara bersama kesimpulan pembelajaran yang sudah berlangsung.

\section{Pertemuan Kedua}

Pemberian penguatan dari peneliti berjalan dengan baik, dimulai dari kegiatan pendahuluan peneliti telah memberikan penguatan verbal di beberapa kegiatan diantaranya peserta didik diminta memeriksa kerapian diri dan kebersihan kelasnya serta tanya jawab pada kegiatan apersepsi seperti: ya pintar, ya bagus dan di kelas yang bersih ada peserta didik yang pintar dan cerdas. Pada kegiatan inti peneliti sudah menyeimbangi antara pemberian penguatan verbal dan pemberian penguatan nonverbal, di sini ada beberapa kegiatan nonverbal diantaranya: mendekati, memegang bahu, senyuman, tepuk tangan, acungan jempol, anggukan, dan mengusap kepala, penguatan berupa tanda sedangkan pada penguatan verbal peneliti lebih banyak menggunakan kata-kata ya, bagus, hebat. Kemudian pada kegiatan penutup peneliti mulai memberikan penguatan pada 2 kegiatan diantaranya pada kegiatan menyimpulkan pembelajaran dan pada kegiatan refleksi pembelajaran, di sini peneliti menggunakan penguatan nonverbal berupa tepuk tangan, acungan jempol kadang-kadang disertai dengan penguatan verbal.

\section{Pertemuan Ketiga}

Pada pertemuan kali ini pemberian penguatan dari peneliti berjalan lebih baik dari pertemuan sebelumnya, dimulai dari kegiatan pendahuluan peneliti peneliti memberikan penguatan verbal dimulai dari kalimat: anak-anak ibu bangga karena semuanya sudah paham dan mengerti tentang pentingnya sikap syukur dan beberapa kata-kata: ya, pintar, bagus, hebat dll, selanjutnya pada kegiatan inti peneliti juga telah menyeimbangi antara pemberian penguatan verbal dengan pemberian penguatan nonverbal, pada penguatan verbal seperti: makin lama tulisanmu makin bagus, ibu suka dengan tulisanmu, tingkatkan terus ya, pekerjaanmu semakin baik, ibu senang dengan pekerjaanmu, pekerjaanmu baik sekali, bagus anak-anak ibu masih tetap semangat siang ini serta beberapa penguatan nonverbal diantaranya:acungan jempol, mengusap kepala, 
mendekati, memegang bahu, senyuman, tepuk tangan, anggukan, dan penguatan berupa tanda, kemudian pada kegiatan penutup peneliti memberikan penguatan verbal yaitu saat menyimpulkan pembelajaran yang sudah berlangsung dan peneliti juga memberikan penguatan nonverbal seperti melakukan kegiatan yang menyenangkan sebelum menutup pembelajaran yaitu dengan bernyanyi yel-yel yang telah dibuat bersama-sama.

\section{Pertemuan Keempat}

Peneliti telah memberikan penguatan verbal dan nonverbal secara baik dan mendekati sempurna yaitu dimulai pada kegiatan pendahuluan peneliti telah memberikan penguatan verbal dengan kata-kata/kalimat seperti: sekarang anak-anak ibu sudah sangat bagus karena tidak pernah lupa akan pentingnya memiliki sikap syukur, ya anak ibu pintar, ya jawabanmu bagus sekali serta beberapa penguatan nonverbal seperti: acungan jempol, tepuk tangan dan anggukan, selanjutnya pada kegiatan inti peneliti juga menyeimbangi antara pemberian penguatan verbal dan nonverbal, diantara penguatan verbal yang diberikan peneliti seperti: bagi anak-anak ibu yang bisa menjawab pertanyaan dengan benar ibu akan berikan stiker senyum dan bintang, bagus, dll dan juga penguatan nonverbal seperti: mendekati, acungan jempol, tepuk tangan, memegang bahu, penguatan berupa tanda, penguatan dengan kegiatan yang menyenangkan, mengusap kepala, merangkul bahu. Kemudian terakhir pada kegiatan penutup peneliti memberikan penguatan verbal dan nonverbal pada saat menyimpulkan pembelajaran yang sudah berlangsung dan pada saat refleksi pembelajaran.

\section{Data Angket Pretest dan Posttest}

Berdasarkan olahan data pretest dan posttest dapat dijelaskan bahwa terdapat perbedaan motivasi belajar siswa sebelum dan sesudah diberikan penguatan dalam proses pembelajaran siswa kelas V SDN 018 Rantau Sialang Kecamatan Kuantan Mudik Kabupaten Kuansing. Sebanyak 85\%atau 23 orang siswa mengalami peningkatan motivasi belajar sedangkan sebanyak15\%atau 4orang siswa memiliki motivasi belajar yang tetap sebelum dan sesudah diberikan penguatan oleh peneliti dalam proses pembelajaran. Disimpulkan bahwa terdapat pengaruh yang signifikan antara pemberian penguatan terhadap motivasi belajar siswa kelas $\mathrm{V}$ SDN 018 Rantau Sialang Kecamatan Kuantan Mudik Kabupaten Kuansing.

\section{Distribusi Frekuensi}

Berdasarkan olahan data mengunakan program SPSS 17,0 for windows adapun pengeluaran distribusi frekuensi dari data pretest motivasi belajar siswa dan posttest motivasi belajar siswa adalah sebagai berikut:

$\mathrm{N}$ atau jumlah data yang valid 27 buah, sedangkan yang hilang (missing) adalah nol. Berarti semua data tentang pretest motivasi belajar siswa dan posttest motivasi belajar siswa bisa di proses.

Mean, rata-rata pretest motivasi belajar siswa(72,63) dan posttest motivasi belajar siswa $(95,41)$. Median, atau titik tengah untuk pretest motivasi belajar siswa (70) dan posttest motivasi belajar siswa (96). Mode, nilai modus pretest motivasi belajar siswa (60) dan posttest motivasi belajar siswa (96).

Standart Deviation, pada penelitian ini, perbandingan antara Mean dan Std. Deviation masing-masing variabel adalah pretest motivasi belajar siswa $(72,63>9,829)$ dan posttest motivasi belajar siswa $(95,41>7.239)$. Berarti hasil ini menunjukkan tidak terdapat data outlier, karena Mean > Std. Deviation.

Range, adalah selisih dari nilai tertinggi dan nilai terendah dalam satu kumpulan data. Secara umum bisa dikatakan, semakin besar rangedata, semakin bervariasi data tersebut. Dalam kasus ini range untuk pretest motivasi belajar siswa(37) dan posttest motivasi belajar siswa (32). Minimum, nilai pretest motivasi belajar siswa(60) dan posttest motivasi belajar siswa (78). Maximum, nilaipretest motivasi belajar siswa(97) dan posttest motivasi belajar siswa (110). Sum, total pretest motivasi belajar siswa(1961) dan posttest motivasi belajar siswa (2576).

\section{Uji Prasyarat}

\section{Uji Normalitas}

Berdasarkan olahan data mengunakan program SPSS 17,0 for windows diketahui nilai sign pretest motivasi belajar adalah $0.796>0.05$ 


\section{PRIMARY : JURNAL PENDIDIKAN GURU SEKOLAH DASAR \\ Volume 8 Nomor 2 Oktober 2019 \\ DOI : http://dx.doi.org/10.33578/jpfkip.v8i1.7566 \\ ISSN : 2303-1514 | E-ISSN : 2598-5949 \\ https://primary.ejournal.unri.ac.id/index.php/JPFKIP}

dan nilai sign untukposttest adalah $0.476>0.05$ maka dapat disimpulkan bahwa data untuk pretest dan posttest berdistribusi normal dan bisa digunakan untuk analisis lebih lanjut.

\section{Uji T}

Karena telah memenuhi syarat tersebut, kemudian dilanjutkan analisis data dengan" $t$ ". bila $\mathrm{n} \_1 \neq \mathrm{n} \_2$ Varians homogen $\left(\sigma \_1^{\wedge} 2=\sigma(2)^{\wedge} 2\right)$ dapat digunakan rumus " $t$ " dengan Pooled varians. Derajat kebebasannya $(\mathrm{dk})=\mathrm{n} \_1+\mathrm{n} \_2-2$.

Berdasarkan olahan data dengan bantuan program SPSS 17,0 for Windows diperoleh nilai Nilai $\mathrm{t}_{\text {hitung }}=7,751$ berarti thitung lebih besar $\mathrm{t}_{\text {tabel }}$ pada taraf signifikan $1 \%$ dan $5 \%$ dengan $(\mathrm{dk})=$ $\mathrm{n} \_1+\mathrm{n} \_2-2$. $\mathrm{Dk}=27+27-2=52$, dengan $\mathrm{df}=$ 52 diperoleh dari $\mathrm{t}_{\text {tabel }}$ pada taraf signifikan $1 \%$ sebesar 1,298 Ini berarti $t_{\text {hitung }}>t_{\text {tabel }}$, dan pada taraf signifikansi $5 \%$ sebesar 1,674 Ini berarti $t_{\text {hitung }}>$ $\mathrm{t}_{\text {tabel}}$, maka diputuskan bahwa $\mathrm{H} 0$ ditolak dan $\mathrm{Ha}$ diterima. Dengan demikian dapat disimpulkan bahwa terdapat pengaruh yang signifikan antara pemberian penguatan terhadap motivasi belajar siswa kelas V SDN 018 Rantau Sialang Kecamatan Kuantan Mudik Kabupaten Kuansing.

\section{Uji Pengaruh (Effect Size)}

Perhitungan uji pengaruh (effect size) sebagai berikut:

$\mathrm{ES}=\left(\mathrm{Y}_{-}^{-} \mathrm{e}-\mathrm{Y}^{-} \mathrm{c}\right) / \mathrm{S} \_\mathrm{c}=(95,41-72.63) / 7.239$ $=22,78 / 7,2 \overline{3} 9=\overline{3}, 146$

Berdasarkan perhitungan tersebut diperoleh ES sebesar 3,146 angka ini termasuk dalam kategori besar karena effect size lebih dari 0,8 . Hal ini dapat disimpulkan bahwa pemberian penguatan berpengaruh terhadap motivasi belajar siswa kelas V SDN 018 Rantau Sialang Kecamatan Kuantan Mudik Kabupaten Kuansing dengan kategori "tinggi". Hal ini menunjukkan bahwa pemberian penguatan (variabel $X$ ) akan mempengaruhi motivasi belajar siswa (variabel Y).

Kontribusi Pengaruh Variabel X terhadap Variabel Y untuk menyatakan besar kecilnya sumbangan pengaruh variabel $\mathrm{X}$ terhadap $\mathrm{Y}$ dapat ditentukan dengan rumus koefisien diterminan (KD) sebagai berikut :

$$
\mathrm{KD}=\mathrm{r} 2 \times 100 \%
$$

Dimana: $\mathrm{KD}=$ Nilai Koefisien Diterminan $\mathrm{r}=$ Nilai Koefisien Korelasi.(Riduwan, 2010)
Berdasarkan perhitungan nilai koefisen determinasi (KD) diperoleh nilai koefisien korelasi (r-square) sebesar 0,35 sehingga jika dihitung dengan mengunakan rumus nilai koefisien determinasi diperoleh hasil sebagai berikut:

$$
\begin{aligned}
& \mathrm{KD}=\mathrm{r} 2 \times 100 \% \\
& =0,35 \times 100 \% \\
& =35 \%
\end{aligned}
$$

Hasil perhitungan diatas menjelaskan bahwa pengaruh variabel $\mathrm{X}$ (Pemberian Penguatan) terhadap variabel Y ( Motivasi Belajar) mampu menjelaskan sebesar $35 \%$ sedangkan sisanya sebesar 65\% (100-35) dipengaruhi oleh variabel lain yang tidak penulis bahas dalam penelitian ini.

\section{Pembahasan}

Berdasarkan hasil penelitian yang telah peneliti lakukan di SDN 018 Rantau Sialang Kecamatan Kuantan Mudik Kabupaten Kuansing bahwasannya terdapat pengaruh yang signifikan antara pemberian penguatan terhadap motivasi belajar siswa hal ini terlihat dari uji t dimana Nilai $t_{\text {hitung }}=7,751$ berarti $t_{\text {hitung }}$ lebih besar dari $t_{\text {tabel }}$ pada taraf signifikan $1 \%$ dan $5 \%$ dengan $(\mathrm{dk})=\mathrm{n} \_1+$ n_2-2. Dk $=27+27-2=52$, dengan $\mathrm{df}=52$ diperoleh dari $t_{\text {tabel }}$ pada taraf signifikan $1 \%$ sebesar 1,298 Ini berarti $t_{\text {hitung }}>t_{\text {tabel }}$, dan pada taraf signifikansi 5\% sebesar 1,674 Ini berarti $\mathrm{t}_{\text {hitung }}>\mathrm{t}_{\text {tabel }}$, maka diputuskan bahwa $\mathrm{H} 0$ ditolak dan Ha diterima. Dengan demikian dapat disimpulkan bahwa terdapat pengaruh yang signifikan antara pemberian penguatan terhadap motivasi belajar siswakelas V SDN 018 Rantau Sialang Kecamatan Kuantan Mudik Kabupaten Kuansing.

Perhitungan tersebutdiperoleh ES sebesar 3,146 angka ini termasuk dalam kategoritinggi karena effect size lebih dari 0,8, dapat disimpulkan bahwa pemberian penguatan berpengaruh terhadap motivasi belajar siswa kelas V SDN 018 Rantau Sialang Kecamatan Kuantan Mudik Kabupaten Kuansing dengan kategoritinggi. Hal ini menunjukkan bahwa pemberian penguatan (variabel $\mathrm{X}$ ) akan mempengaruhi motivasi belajar siswa (variabel Y).

Hasil penelitian ini sesuai dengan teori yang mengatakan bahwa pemberian penguatan mempengaruhi motivasi belajar siswa. Pemberian 


\section{PRIMARY : JURNAL PENDIDIKAN GURU SEKOLAH DASAR \\ Volume 8 Nomor 2 Oktober 2019 \\ DOI : http://dx.doi.org/10.33578/jpfkip.v8i1.7566 \\ ISSN : 2303-1514 | E-ISSN : 2598-5949 \\ https://primary.ejournal.unri.ac.id/index.php/JPFKIP}

Penguatan (reinforcement) merupakan tindakan atau respon terhadap suatu bentuk perilaku yang dapat mendorong munculnya peningkatan kualitas tingkah laku tersebut (Majid, 2017) pemberian penguatan disini hanya dalam bentuk reward.

Ada beberapa faktor yang mempengaruhi keberhasilan siswa dalam pendidikan. Salah satu faktor eksternal yang menentukan keberhasilan kegiatan pembelajaran di sekolah adalah faktor guru dan cara mengajarnya. Agar dapat mencapai tujuan dalam pembelajaran, seorang guru harus memiliki kompetensi untuk menunjang pencapaian tujuan tersebut. Usman (2011) menyebutkan salah satu kompetensi yang harus dimiliki oleh guru adalah keterampilan memberi penguatan. Guru dalam proses belajar mengajar hendaknya dapat memahami siswanya, salah satunya adalah dengan memberikan penguatan. Usman (2011) mengemukakan penguatan (reinforcement) adalah segala bentuk respon yang bersifat verbal ataupun nonverbal sebagai umpan balik yang diberikan terhadap tingkah laku siswa.

Fenomena di lapangan menunjukkan bahwa siswa yang mendapatkan penguatan oleh guru dalam kegiatan pembelajaran memiliki motivasi belajar yang tinggi serta terpacu untuk melakukan pekerjaan. Pemberian penguatan menjadi tanggung jawab guru dalam mengajar, keberhasilan tersebut banyak tergantung pada usaha untuk dapat membangkitkan motivasi.Mc Clelland (dalam Uno, 2011) "Amotive isthere dintegration by a cueof achangein an affective situasion", yang berarti motif merupakan implikasi dari hasil pertimbangan yang telah dipelajari (redintegration) dengan ditandai suatu perubahan pada situasi afektif. Menurut Uno (2011) motivasi belajar dapat timbul karena faktor instrinsik yang salah satunya merupakan dorongan kebutuhan belajar dan faktor ekstrinsik yang salah satunya berupa penghargaan.

Tugas guru sebagai pendidik adalah meningkatkan motivasi belajar siswa, yaitu dengan memberikan rangsangan berupa penghargaan/pujian, dan nasehat. Djamarah (2010) mengemukakan tujuan penggunaan keterampilan pemberian penguatan di kelas dapat memberi motivasi kepada siswa, mengontrol atau mengubah tingkah laku yang kurang baik. Individu selalu memerlukan perhatian, pujian, sapaan sebagai suatu bentuk penguat tingkah laku. Bila siswa mendapat pujian dari gurunya, maka siswa tersebut menjadi bersemangat dan dapat meningkatkan rasa percaya dirinya.

Penguatan menjadi salah satu dari delapan keterampilan dasar mengajar guru yang sangat berperan dalam proses belajar mengajar. Hal ini dikarenakan penguatan dapat mengubah perilaku siswa.Saidiman (dalam Uno, 2011) menyatakan bahwa penguatan merupakan tingkah laku guru dalam merespon secara positif suatu tingkah laku tertentu siswa yang memungkinkan tingkah laku tersebut timbul kembali.Senada dengan hal tersebut, salah satu tujuan penguatan yang dikemukakan oleh Usman (2011) yaitu "merangsang dan meningkatkan motivasi belajar". Dengan demikian, tujuan pemberian penguatan saling berkesinambungan, karena dengan adanya penguatan sehingga motivasi siswa dalam memahami pelajaran akan meningkat. Diharapkan dengan adanya motivasi belajar yang timbul, maka siswa akan bersemangat dalam belajar sehingga dapat meningkatkan hasil belajarnya.

Begitu pula halnya dengan siswa yang bertingkahlaku kurang baik, dengan adanya penguatan yang diberikan oleh guru, diharapkan tingkah laku yang kurang baik tersebut dapat dihilangkan dan menjadi lebih baik lagi. Motivasi merupakan salah satu prasyarat yang amat penting dalam belajar. Segala fasilitas belajar yang lengkap dengan harapan supaya siswa dapat masuk sekolah dan belajar dengan penuh semangat. Tetapi semua itu akan sia-sia, jika siswa tidak memiliki motivasi untuk belajar. Menurut Uno (dalam Cahayani, 2015) semua anak memiliki motivasi, namun tidak semua anak termotivasi untuk bertingkah laku baik.Sebagian motivasi timbul dari diri siswa dan sebagian lagi timbul dari luar. Motivasi internal dan eksternal bekerja bersama-sama untuk membuat siswa menjadi orang yang bertanggung jawab. Motivasi dikatakan sebagai keseluruhan daya penggerak baik dalam diri siswa (Motivasi Intrinstik) maupun dari luar siswa (Motivasi Ekstrinsik). Daya penggerak itulah yang dapat menimbulkan kegiatan belajar mengajar itu sendiri sehingga tujuan yang dikehendaki dapat tercapai. Apabila mengharapkan motivasi selalu muncul atau datang dalam diri siswa merupakan hal yang tidak mungkin, hal ini dikarenakan tingkat 
motivasi siswa cendrung berubah-ubah.Selain itu banyak yang harus diperlajari oleh siswa setiap hari di sekolah.

Pada dasarnya kegiatan belajar mengajar tidaklah selalu menarik, belum lagi banyaknya mata pelajaran yang harus dipelajari. Oleh karena itu perlu adanya penguatan salah satunya yaitu penguatan baik yang bersifatverbal maupun nonverbal dari guru dalam pembelajaran. Ada banyak upaya yang dapat dilakukan untuk menumbuhkan dan meningkatkan motivasi belajar siswa, penguatan verbal maupun nonverbal merupakan unsur yang paling penting dalam proses pembelajaran. Hal ini sesuai dengan pendapat Uno (dalam Cahayani, 2015) yang menyatakan bahwa salah satu teknik motivasi dalam pembelajaran yaitu dengan pernyataanpenghargaan secara verbal yang dilakukan dengan baik terhadap perilaku siswa merupakan cara paling mudah dan efektif untuk meningkatkan motivasi belajar siswa.

Penelitian yang dilakukan ini menunjukkan hasil yang sejalan dengan penelitian Sulaiman (2014). Berdasarkan hasil penelitian yang telah peneliti lakukan menjelaskan bahwa besarnya pengaruh pemberian penguatan terhadap motivasi belajar siswa kelas V di SDN 018 Rantau Sialang tergolong tinggi, hal ini ditunjukkan dengan kontribusi pengaruh variabel $X$ (pemberian penguatan) terhadap variabel Y (motivasi belajar) mampu menjelaskan sebesar 35\%, sedangkan penelitian yang dilakukan oleh Sulaiman (2014) disimpulkan bahwa pemberian penguatan (reinforcement) oleh guru terhadap motivasi belajar siswa dikelas IV SDN Unggul menurut Aceh besar tergolong tinggi. Hal ini terbukti dengan hasil perhitungan menunjukan koefisien korelasi sebesar 0,914 sehingga koefisisen determinasinya adalah 0,835 . Hal ini menunjukan bahwa variabel penguatan memiliki pengaruh kuat terhadap motivasi belajar siswa sebesar $83.5 \%$.

Penelitian yang dilakukan oleh Cahayani (2015) dan Suhanda (2017) menunjukkan besarnya pengaruh pemberian penguatan terhadap motivasi belajar siswa tergolong cukup atau sedang. Berdasarkan penelitian Cahayani (2015) pengaruh pemberian penguatan verbal terhadap motivasi belajar siswa kelas V SDN Se-Gugus Krida Mandala tergolong sedang dengan koefisien $r$ sebesar 0,442, jadi kontribusi variabel $\mathrm{X}$ terhadap variabel Y sebesar 19,5\%. Selanjutnya dalam penelitian yang dilakukan oleh Suhanda (2017) berdasarkan hasil uji hipotesis diperoleh nilai koefisien korelasi theta 0,40625, bila dikonsultasikan pada tabel interval nilai koefisien korelasi maka berada pada kategori cukup atau sedang. Artinya menunjukkan bahwa pemberian penguatan verbal positif yang digunakan cukup berpengaruh terhadap motivasi belajar siswa.Tingginya kontribusi pengaruh yang diberikan oleh variabel $X$ (pemberian penguatan) terhadap variabel Y (motivasi belajar) disebabkan oleh beberapa faktor diantaranya, upaya guru dalam membelajarkan siswa yang mana pelaksanaan pemberian penguatan yang dilakukan dalam proses pembelajaran berlangsung dengan baik. Sehingga motivasi belajar siswa juga ikut baik, unsur-unsur dinamis dalam belajar dan pembelajaran guru dapat membawa siswa untuk dapat melakukan kegiatan dalam pembelajaran, kemampuan siswa dalam belajar, kondisi siswa yang meliputi jasmani dan rohaninya dan kondisi lingkungan belajar siswa yang menyenangkan. Sehingga pengaruh pemberian penguatan sangat diperlukan di sekolah tersebut. Kemudian cukup atau sedangnya kontribusi pengaruh yang diberikan oleh variabel $X$ (pemberian penguatan) terhadap variabel $\mathrm{Y}$ (motivasi belajar) disebabkan oleh banyaknya faktor-faktor yang mempengaruhi motivasi belajar siswa seperti pestasi belajar, kemandirian belajar, bakat dan minat siswa, sehingga pemberian penguatan di sekolah tempat penelitian tersebut tidak terlalu diperlukan oleh siswa, karena minat siswa dalam belajar itu sudah tinggi, prestasi belajarnya pun sudah bagus, kemandirian belajar siswa juga sudah tinggi.Berdasarkan penelitian yang telah peneliti lakukan dan beberapa penelitian lainnya dapat disimpulkan bahwa terdapat pengaruh yang signifikan antara pemberian penguatan terhadap motivasi belajar siswa. 


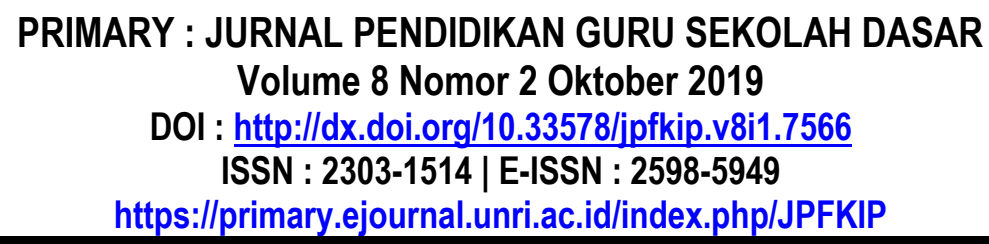

\section{SIMPULAN DAN REKOMENDASI}

Berdasarkan pengolahan dan analisis data yang telah peneliti lakukanmenunjukkan bahwa terdapat peningkatan motivasi belajar siswa sebelum dan sesudah diberikan penguatan. Hal ini ditunjukkan dari uji $\mathrm{t}$ yaitu $\mathrm{t}_{\text {hitung }}>\mathrm{t}_{\text {tabel }}$ pada taraf signifikan $1 \%$ maupun $5 \% .(1,298<7,751>1,674)$ maka diputuskan bahwa $\mathrm{H}_{0}$ ditolak dan $\mathrm{H}_{\mathrm{a}}$ diterima, dengan demikian dapat disimpulkan bahwa terdapat pengaruh pemberian penguatan terhadap motivasi belajar siswa kelas V SDN 018 Rantau Sialang Kecamatan Kuantan Mudik Kabupaten Kuansing.

\section{DAFTAR PUSTAKA}

Cahayani, D. R (2015). Pengaruh Pemberian Penguatan Verbal Terhadap Motivasi Belajar Siswa Kelas V SD Negeri SeGugus Krida Mandala Kecamatan Purwokerto Selatan Kabupaten Banyumas. Universitas Negeri Semarang.

Daud, D., dkk. (2009). Pemantapan Kemampuan Belajar.Pekanbaru: Cendikia Insani.

Djamarah, S. B. (2010). Guru dan Anak Didik dalam Interaksi Edukatif. Jakarta: Rineka Cipta.

Kompri. (2015). Motivasi Pembelajaran Perspektif Guru dan Siswa. Bandung: PT Remaja Rosdakarya.

Majid, A. (2017). Strategi Pembelajaran. Bandung: PT Remaja Rosdakarya.

Riduwan, A. (2010). Rumus dan Data dalam Aplikasi Statistik. Bandung: Alfabeta.

Sardiman. (2016). Interaksi dan Motivasi Bealajar. Jakarta: PT Raja Grafindo Persada.

Sugiyono. (2017). Metode Penelitian Kuantitatif, Kualitatif dan $R \& D$. Bandung: Alfabeta.

Suhanda, A. I. (2017). Pengaruh Pemberian Penguatan Terhadap Motivasi Belajar Siswa. Jurnal Pendidikan Dan Penelitian Sejarah, 5 (5), 112-426.

Sulaiman. (2014). Pengaruh Pemberian Penguatan (Reinforcement) Oleh Guru Terhadap Motivasi Belajar Siswa Di Kelas IV SD Nunggul Lampeuneurut Aceh Besar. Jurnal Pesona Dasar, 2 (3), 85-93.

Uno, H. B. (2011). Teori Motivasi dan Pengukurannya. Jakarta: Bumi Aksara.
Berdasarkan hasil penelitian diatas maka peneliti menyarankan beberapa hal sebagai berikut:

1. Guruhendaknya selalu memberikan penguatan kepada siswa dalam proses pembelajaran.

2. Siswa sebaiknya dapat memperhatikan dan mempertahankan motivasi belajar dengan baik agar dapat meningkatkan hasil belajar nantinya.

3. Diharapkan pada peneliti selanjutnya agar dapat memperluas populasi dan memperbanyak jumlah sampel agar mendapatkan hasil yang lebih baik.

Usman, M. U. (2011). Menjadi Guru Profesional. Bandung: Rosdakarya. 